Orellana-Macías, J. M., L. M. Bautista, D. Merchán, J. Causapé, and J. C. Alonso. 2020. Shifts in crane migration phenology associated with climate change in southwestern Europe. Avian Conservation and Ecology 15(1):16. https://doi.org/10.5751/ACE-01565-150116

Copyright (C) 2020 by the author(s). Published here under license by the Resilience Alliance.

Research Paper

\title{
Shifts in crane migration phenology associated with climate change in southwestern Europe
}

\author{
José M. Orellana-Macías ${ }^{1}$, Luis M. Bautista ${ }^{2}$, Daniel Merchán ${ }^{3}$, Jesús Causapé ${ }^{1}$ and Juan Carlos Alonso ${ }^{2}$ \\ ${ }^{1}$ Instituto Geológico y Minero de España, ${ }^{2}$ Museo Nacional de Ciencias Naturales (CSIC), ${ }^{3}$ Universidad Pública de Navarra
}

\begin{abstract}
Gallocanta lagoon, NE Spain, is one of the main stopover and wintering areas of Common Cranes (Grus grus) migrating through Western Europe. We investigated how the water level of the lagoon where cranes roost, precipitation, and air temperature might have influenced the species' migration and wintering patterns in this area between 1973 and 2018. Over the study period, the mean annual air temperature increased at $0.3{ }^{\circ} \mathrm{C}$ per decade. Simultaneously, cranes advanced the spring peak migration date at a rate of 0.37 days/year. Water level and rainfall during spring were also positively correlated with the date of spring migration peak. Because cranes need shallow water to roost, and must drink water from streams because the lagoon is saline, these correlations suggest that low water levels at roosting sites and drinking water shortage may have further accelerated the onset of northward spring migration. The water level was also positively correlated with peak crane numbers in autumn, suggesting that the roosting capacity of the lagoon may limit numbers of cranes that can stopover in the area. We conclude that global warming, variations in the water level of the lagoon, and precipitation during spring have determined changes in the use of Gallocanta as a staging and wintering area by Common Cranes during the last decades. Because climatic models predict further decreases in rainfall and higher temperatures in the area, further advances in the migration phenology of cranes should be expected, which might also have implications for the conservation and management of the species and the study area.
\end{abstract}

\section{Modification de la phénologie de migration des grues associé aux changements climatiques dans le sud-ouest de l'Europe}

RÉSUMÉ. La lagune Gallocanta, dans le nord-est de l'Espagne, est l'une des principales haltes et aires d'hivernage de la Grue cendrée (Grus grus) qui migre dans l'ouest de l'Europe. Nous avons examiné de quelle façon le niveau d'eau de la lagune où les grues dorment, les précipitations et la température de l'air ont pu influer sur les tendances de migration et d'hivernage de l'espèce dans ce secteur entre 1973 et 2018. Au cours de cette période, la température moyenne annuelle de l'air a augmenté de $0,3{ }^{\circ} \mathrm{C}$ par décennie. Simultanément, les grues ont devancé la date de leur pic migratoire printanier au taux de 0.37 jour/année. Le niveau d'eau et les précipitations au printemps ont aussi été positivement corrélés avec la date du pic migratoire printanier. Parce que les grues ont besoin d'eau peu profonde pour y dormir et qu'elles doivent boire de l'eau à partir de ruisseaux étant donné que la lagune est salée, ces corrélations indiquent que de faibles niveaux d'eau aux dortoirs et un manque d'eau potable ont peut-être accéléré encore plus l'initiation de la migration printanière vers le nord. Le niveau d'eau était aussi corrélé positivement avec le nombre maximum de grues en automne, laissant entrevoir que la capacité de rassemblement à la lagune limite sans doute le nombre de grues qui peut s'arrêter dans le secteur. Nous concluons que le réchauffement climatique, les variations du niveau d'eau de la lagune et les précipitations au printemps ont été responsables du changement dans l'utilisation de Gallocanta comme halte et aire d'hivernage par les Grues cendrées durant les dernières décennies. Puisque les modèles climatiques prédisent encore moins de précipitations et des températures plus élevées dans le secteur, on peut s'attendre à un avancement encore plus prononcé de la phénologie de migration des grues, ce qui pourrait aussi avoir des répercussions sur la conservation et la gestion de l'espèce et de l'aire d'étude.

Key Words: avian migration; Common Crane; Gallocanta Lake; Global Warming; Grus grus

\section{INTRODUCTION}

Migratory birds have been instrumental for understanding climate-change effects because they show a wide array of changes in migration phenology, but there are still many aspects that need further research (Knudsen et al. 2011, Dunn and Møller 2019). For example, an earlier arrival at the breeding or wintering areas may occur through a reduction in duration of the migratory trip, either by flying faster or by shortening the stay at stopover sites, but also by advancing the departure date. Although the onset of migration is determined endogenously, its timing is flexible and can be modified in response to changes in weather and phenology along migration routes (Marra et al. 2005). Such flexibility in migration speed and stopover duration, however, seems insufficient to adjust to ongoing climate change and is unlikely to explain the observed arrival advancements in some species (Knudsen et al. 2011, Charmantier and Gienapp 2014, Schmaljohann and Both 2017). On the other hand, even closely related species differ in their phenological responses, and the causes of these interspecific variations are still poorly understood (Végvári et al. 2010, Bauer et al. 2016). Thus, examining spring phenology in both wintering and breeding grounds is important to understand the mechanism of phenological shifts. 
The timing of spring migration is essential for successful reproduction in north-temperate breeding areas (Kokko 1999, Visser et al. 2006). An early arrival can result in higher productivity by increasing the chances of acquiring better territories (Aebischer et al. 1996, Smith and Moore 2005) or retaining those of previous seasons (e.g., Forstmeier 2002). It also helps coupling food availability and food requirements (e.g., Dunn et al. 2011). Additionally, early breeders have more time to recover from migration before starting reproduction, and to raise their offspring on time before the next autumn migration (Ramenofsky and Wingfield 2007). In sight of these advantages of an early arrival at the breeding areas, the influence of the alterations enhanced by climatic conditions and their magnitude should be investigated in wintering and stopover sites to make reliable predictions related to phenological shifts.

Common Cranes (Grus grus), like most other crane species, are long-lived birds that perform long migrations between breeding and wintering areas. Thus, they are suitable to investigate whether changes in migratory patterns are associated to climate changes. For example, Whooping Cranes (Grus americana) advanced the spring migration by 22 days and delayed the autumn migration by 21 days over the last 75 years (Jorgensen and Brown 2017), overwintering in new sites where climate changes have resulted in higher temperatures and more agricultural food resources (Teitelbaum et al. 2016).

The breeding, stopover, and wintering sites of Common Cranes in the western Palearctic are well known (Prange 2016, Ojaste et al. 2020) and their migration phenology has been recorded over several years at different sites (Bautista et al. 1992, FilippiCodaccioni et al. 2011, Knudsen et al. 2011, Mingozzi et al. 2013, Salvi 2016, LPO/Birdlife 2018). However, the drivers of changes in phenology are mostly unknown. In recent years, Common Cranes arrive earlier at their breeding areas (Lundgren 2012, Salvi 2016, Palm et al. 2017), abandon them earlier in summer (FilippiCodaccioni et al. 2011), and also pass earlier through postbreeding stopover sites (Kraft 1999, Végvári 2015). However, it is unclear whether Common Cranes also arrive earlier at their wintering sites in southwestern Europe. An early arrival at the breeding sites suggests that they could leave their wintering sites earlier. On the other hand, although most Common Cranes still overwinter at their traditional areas in southwestern Europe (Prange 2005, Román 2018), some have reduced the migration distance and currently spend the winter closer to the breeding areas (e.g., Mewes and Rauch 2012, Nowald et al. 2012, Salvi 2012). Unlike in autumn, spring staging is short and apparently determined by weather conditions, although the causes of such a brief staging are still poorly understood (Alonso et al. 1990a, b).

In this study we investigate the relationships between migration and climate in the Common Crane phenology during five decades at Gallocanta Lake, one of the most important wintering and stopover sites in the species' western migratory flyway. This lake and the surrounding agricultural fields have been used by increasing numbers of Common Cranes as a staging and wintering area since the early 1970s (Alonso et al. 1987a, $b$, Bautista et al. 1992). The factors responsible for this increase were an enhanced protection of the area (Bautista et al. 1992), higher food availability (Alonso et al. 1994), and an increase in the size of the species' population in Western Europe (Alonso et al. 2008,
Prange 2012). Previous studies of the effects of weather during the prebreeding migration in Gallocanta showed higher migration intensity on sunny days with tail winds (Alonso et al. 1990a, $b$ ). But the long-term effects of climate on the spring and autumn migration phenology at Gallocanta are unknown. We proposed the following hypotheses. First, based on the correlation found between increasing air temperatures and delayed autumn migration in northern Europe (Prange 2012, Volkov et al. 2016), and on similar effects of climatic predictors on spring and autumn migration phenology in eastern European stopover sites (Végvári and Kovacs 2012, Végvári 2015), we hypothesized that an increase in temperature, the most used indicator of climate change, could have detectable effects on the timing of Common Crane migration in southwestern Europe. Second, we hypothesized that low precipitation can modify the staging and wintering patterns of Common Cranes. Insufficient rainfall at wintering sites may reduce the amount of food and drinking water available for Common Cranes (Alonso et al. 1994, Harris and Archibald 2013) and dry up the shallow lagoons that provide safe roosting sites. In Gallocanta, annual rainfall and water depth of the lagoon have decreased since 1974 (Castañeda and Herrero 2009, García et al. 2009), and thus the peak counts during spring and autumn migrations should have dropped. However, numbers have increased (Bautista et al. 1992), though this could be due to the increase of the Common Crane population in the Western Palearctic (Alonso et al. 2016, Prange 2016). Based on the weak relationship between annual rainfall and lake level (Kuhn et al. 2011), we explored the effects of both rainfall and water level of the lagoon on Common Crane numbers and migration dates. Our aim in this study was therefore to determine if Common Crane phenology at Gallocanta changed between 1973 and 2018 in both autumn and spring migrations, and how these changes were related to air temperature as a measure of global warming, but also to other variables that provide essential resources to Common Cranes, namely rainfall and water level of the lagoon.

\section{METHODS}

\section{Study area}

Gallocanta is an endorheic basin of 54,335 ha surrounding an ephemeral saline lake $\left(40^{\circ} 58^{\prime} \mathrm{N}, 1^{\circ} 30^{\prime} \mathrm{W}, 990 \mathrm{~m}\right.$.a.s.1.) with a water surface of approximately 1330 ha (Iglesias and Bone 2006). Salinity ranges between 0.5 and $49.4 \mathrm{dS} / \mathrm{m}$, being higher when the water level is low. This basin is located in the central sector of the Iberian Range, in the NE Iberian Peninsula. The climate is semiarid and has a strong continental and altitudinal influence. Summers are hot and winters are cold with little rainfall. The average annual temperature is $11.6{ }^{\circ} \mathrm{C}$, but the continental and altitudinal influences lead to a great temperature variation, i.e., minimum values of around $-20{ }^{\circ} \mathrm{C}$ and maximum above $35^{\circ} \mathrm{C}$. The average annual rainfall is around $440 \mathrm{~mm}$, gathered mostly in spring and autumn but with strong interannual variation. Most of the land is intensively cultivated (35,637 ha; CORINE 2018), mainly with wheat and barley, and some sunflower.

\section{Meteorological series}

Time series of air temperature and precipitation were obtained from 1973 to 2018. Meteorological data include daily mean air temperatures and daily rainfall. From daily mean air temperature and daily rainfall we calculated annual mean air temperature and 
annual rainfall. The data were obtained from a meteorological station located in Gallocanta $\left(40^{\circ} 59^{\prime} 0^{\prime \prime} \mathrm{N}, 1^{\circ} 30^{\prime} 32^{\prime \prime} \mathrm{W}\right)$, next to the lake. Because Gallocanta meteorological series were not complete for the study period, daily temperatures and precipitation series from meteorological stations across the study area provided by the Spanish State Meteorological Agency (AEMET, http://www.aemet.es/en/portada) were interpolated by using the inverse distance weighting (IDW) of meteorological variables. IDW has been widely used to interpolate meteorological variables (Kurtzman et al. 2009, Chen and Liu 2012), and it is recognized as one of the most common techniques for interpolation. The IDW formulas are described in Equations 1 and 2.

$$
\begin{aligned}
& \mathrm{R}_{0}=\sum_{i=1}^{n}\left(w_{i} \cdot R_{i}\right) \\
& \mathrm{w}_{i}=\frac{d_{i}^{-\alpha}}{\sum_{i=1}^{n} d_{i}^{-\alpha}}
\end{aligned}
$$

Where the estimated variable (in $\mathrm{mm}$ or ${ }^{\circ} \mathrm{C}$ ); is variable measured at point; is the number of meteorological stations used for interpolation; is the weighting of each meteorological station; is the distance from each meteorological station to the estimated point; and is the power coefficient set as $=2$ in this study. IDW estimate values for unsampled locations were based on weighted values of known points around those locations. The value at the unknown location is the weighted sum of the values of known points based on the distance between the known points and the estimated point.

The interpolation was evaluated with two different statistics: mean absolute error (MAE) and bias. The MAE is calculated as the mean of the absolute differences between predicted and observed values and shows the magnitude of the error regardless of its sign. The bias is calculated as the mean of the differences between estimated and observed values and shows the tendency to overestimate or underestimate the interpolated variable.

Validation tests applied to interpolated data showed low MAE $\left(23 \mathrm{~mm}\right.$ and $\left.0.6^{\circ} \mathrm{C}\right)$ and $\operatorname{BIAS}\left(21 \mathrm{~mm}\right.$ and $\left.0.6^{\circ} \mathrm{C}\right)$. Precipitation mean error was $6 \%$ of the rainfall amount, whereas temperature mean error was $5 \%$. Both estimations slightly overestimated precipitation and temperature. However, MAE and BIAS values were low, so we accepted interpolated data.

\section{Lake water level}

From 1973 to 2015 the regional water management authority (Ebro Hydrographic Confederation, CHE) measured the water level daily or weekly (Confederación Hidrográfica del Ebro 1997, 2002, 2003). Since 2015, water level sensors connected to an automated electronic recorder collected the water level every hour. In addition, water level data that were recorded occasionally by wildlife guards at roughly the same times, and evenly across the sampling period, were also included in this study. The combination of data sources allowed us to assemble a continuous series of water depths from 1974 to 2018 and calculate the annual mean water depth at the measurement point.

\section{Common Crane censuses}

Common Cranes usually arrive at Gallocanta between October and December. A variable number of birds remain there throughout the winter, whereas most continue migrating to their traditional wintering areas in southwestern Spain. Prebreeding northward migration takes place between late February and early April.

Experts in conducting censuses made Common Crane counts. Before 1979, the Common Crane population arriving at Gallocanta was surveyed on a weekly to fortnightly basis by wildlife guards (Hernández 1986). Beginning in 1979, counts were increased to one to two times per week (Bautista et al. 1992). Two to six observers counted Common Cranes that left the roosts in early morning after sleeping there, then returned in the evening. Since 2005, guards counted Common Cranes weekly between October and March (Gobierno de Aragón 2018). Birdwatchers provided a few additional censuses (e.g., Prieta and del Moral 2009, Sampietro et al. 2017, Román 2018). All these counts followed the same census protocol, so the small changes in survey frequencies over the study period (one to two times per week as a rule, one time per fortnight only on the years 1973-1979) have not caused any major bias when calculating mean or maximum crane numbers during both migrations or in winter.

\section{Statistical analyses of numbers of Common Cranes}

As mentioned above, we worked with the maximum numbers of Common Cranes in both migrations (autumn: postbreeding, spring: prebreeding) and the minimum numbers in winter (January). Because the western population of Common Cranes showed a clear increase (Alonso et al. 2016), the observed number of Common Cranes was standardized according to the number of Common Cranes counted in the last year (i.e., 2018) with Equation 3:

$$
V_{i}=\frac{\left(V_{m t} \cdot D_{i}\right)}{100}+V_{m t}
$$

Where the standardized number of Common Cranes in year $i$, is the maximum number of Common Cranes counted in 2018, and is the difference between the theoretical observation and the measured observation of Common Cranes each year in percentage. After controlling for the historical increasing trend we analyzed the effects of meteorological factors and other abiotic variables on the seasonal number of Common Cranes across years.

We also analyzed the historical trend of wintering Common Cranes, bearing in mind that the number of wintering Common Cranes must be a fraction of the Common Crane population staging in autumn. As a proxy of the proportional number of Common Cranes that overwintered in Gallocanta, we calculated the ratio between the minimum number of wintering Common Cranes (January) and the maximum counted in the previous autumn migration. Everything else being equal, it can be assumed that the higher the maximum in autumn, the higher the minimum number of Common Cranes overwintering in Gallocanta.

The variability across years can mask a historical trend in the number of Common Cranes, thus a Mann-Kendall seasonal test was calculated. The nonparametric Mann-Kendall test calculates a trend and the level of statistical significance of such trend in temporal series. Trend analysis is completed by using Sen's slope, which quantifies the calculated trend in the number of Common Cranes (Helsel and Hirsch 2002). Correlations were calculated 
with the nonparametric Kendall's correlation coefficient. Statistical and trend analyses were performed with the MAKESENS Microsoft Excel Template (Salmi et al. 2002), and correlation analysis and regression models with the Trend Package from R software (R Development Core Team 2016) and JMP software.

\section{Statistical analyses of migration dates}

For the purpose of comparing changes in migration times, standardized bird-banding data may be preferable to bird counts (Miller-Rushing et al.2008), but a sufficient number of resightings of banded Common Cranes was not available. We analyzed the Julian dates when maximum numbers of Common Cranes were counted at the lake in autumn and spring as proxies of the migration timing in Gallocanta. We disregarded dates of early and late migrations because detailed counts of Common Cranes arriving early in autumn or leaving late in spring were not available. Additionally, the increase in numbers of Common Cranes in the western population probably contributed to extend the length of the migratory period over the years, and therefore the first and last dates of migration could be worse estimators of the migration phenology than the dates of maximum Common Crane counts. We also provided additional results of dates corresponding to the 50th percentile of Common Crane counts during autumn and spring migrations, because quantifying the entire seasonal distributions of migration dates could result in more stable inferences than relying on a single date of maximum bird counts (Cohen et al. 2015).

To assess the influence of abiotic conditions over migration dates, we performed single and multiple regression models for both spring and autumn migrations. In the models we included abiotic conditions (temperature, rainfall, and water level) as independent variables, and the dates of maximum number and 50th percentile of Common Cranes as dependent variables.

In addition to statistical analyses of historical trends (1970-2018), short-term variability in abiotic variables (weather, temperature, etc.) would add seasonal variability in dates of migration peaks. The abiotic variables in spring (January-March) and autumn (October-December) were included in a correlation analysis in order to isolate the influence of seasonal conditions over the migratory peaks. Seasonal effects of weather and other abiotic variables in dates of maximum migration were calculated with the residuals of a linear model of the historical trends of the abiotic variables. We included the residuals of seasonal mean temperature, rainfall, mean water level at the lake, and North Atlantic Oscillation (NAO) index in spring and autumn as predictor variables of seasonal changes in the date of the migration peak.

\section{RESULTS}

\section{Weather series and water level of the lagoon}

Between 1973 and 2018 the air temperature increased $0.3{ }^{\circ} \mathrm{C}$ per decade $(\mathrm{P}<0.001)$. This increase was fairly linear, totaling $\sim 1.4^{\circ}$ $\mathrm{C}$ over the study period (Fig. 1). Annual rainfall showed a statistically nonsignificant decrease.
Fig. 1. Mean annual air temperature (top), annual precipitation (middle), and water level of the lagoon (bottom) in Gallocanta between 1973 and 2018. Temporal trends (highlighted with linear regression fitting lines) are statistically significant $(\mathrm{P}<0.001)$ for air temperature increase and water level decrease (continuous lines). Annual precipitation did not show a significant temporal trend (dashed line).

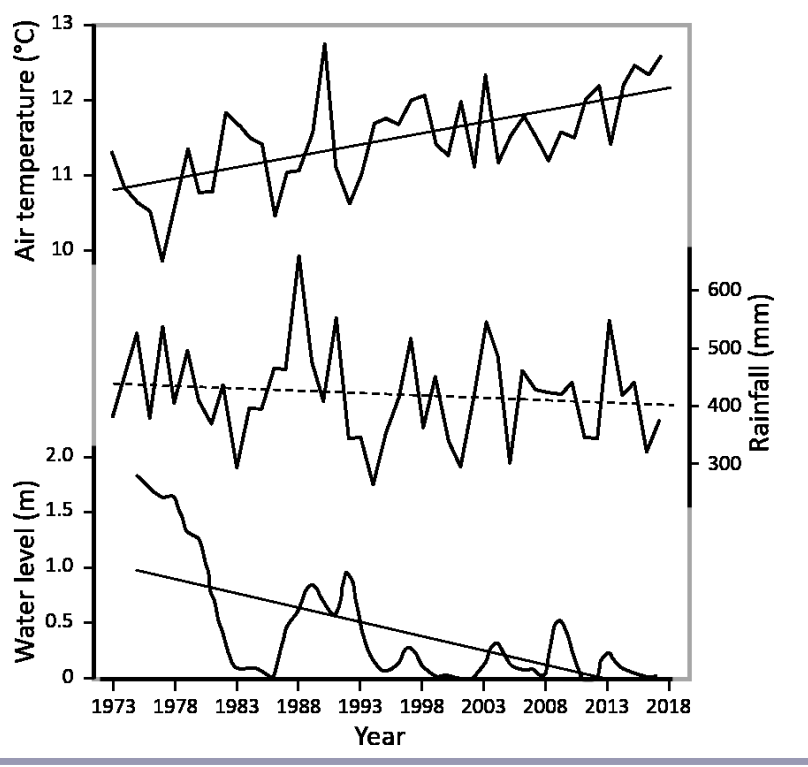

The main characteristic of water level values was a strong interannual and intra-annual variation. On May 1974 the water level was around $2 \mathrm{~m}$, the highest value during the study period. After 1983 it fluctuated across years (Fig. 1, bottom series), between extremely dry years and long periods of open water, always below $1 \mathrm{~m}$.

Water level correlated negatively with air temperature (Kendall $\tau$ $=-0.40, \mathrm{P}<0.001)$ and positively with rainfall (Kendall $\tau=0.21$, $\mathrm{P}=0.049)$. Air temperature and rainfall were not correlated $(\mathrm{P}>$ $0.05)$.

\section{Historical trends of Common Crane numbers in Gallocanta and their relation with weather}

The maximum number of Common Cranes in Gallocanta increased over the study period, from a few hundred individuals in 1973 to many thousands in the last years (the peak was 120,000 birds on a single day in February 2011). The increase was slightly different in each migration season and study stage: during the first 15 years of the study period, greater maximum numbers of Common Cranes were observed in autumn than in spring, while in the last 10 years the reverse was observed (Fig. 2). The overall increase in maximum numbers was $>600$ Common Cranes/year in autumn and $>1000$ Common Cranes/year in spring.

Over the period 1983-2018, when water level of the lagoon oscillated, the standardized maximum number of Common Cranes in autumn was significantly correlated with water level (Kendall $\tau=0.38, \mathrm{P}=0.002$; Fig. 3), but not with temperature 
Fig. 2. Maximum numbers of Common Cranes (Grus grus) counted in Gallocanta during the autumn (top) and spring (bottom) migration periods, and minimum number during the overwintering period (middle). Temporal trends (highlighted with linear regression fitting lines) are all statistically significant $(\mathrm{P}<0.001)$.

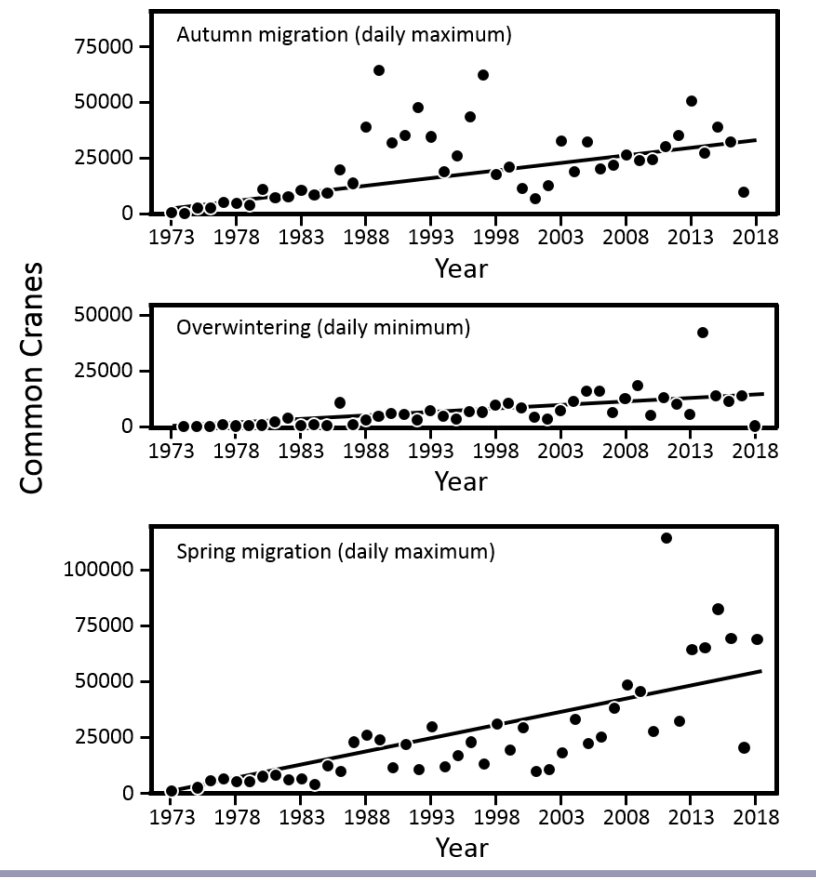

Fig. 3. Relationship between the maximum number of Common Cranes (Grus grus) in autumn migration (period 1983 to 2018) and the annual mean of water level. Numbers of Common Cranes were previously standardized to the autumn peak of year 2018 to control for the population increase along the study (see Methods). The line shows a linear regression fit $(\mathrm{P}<$ 0.001).

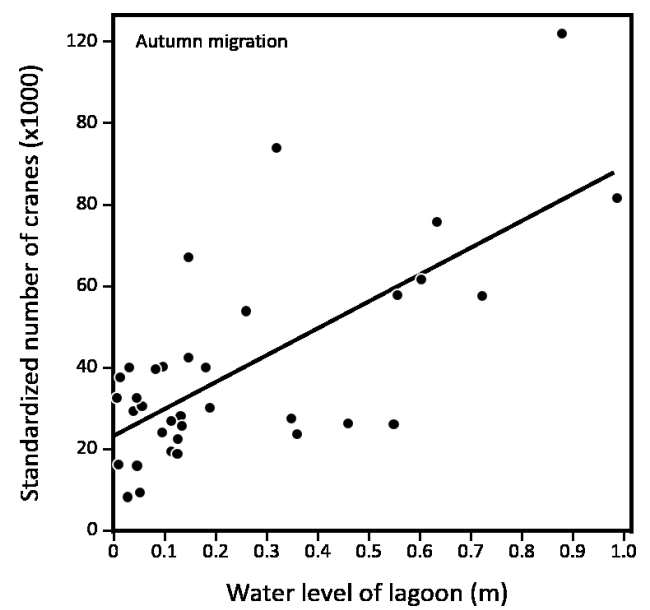

(Kendall $\tau=-0.11, P=0.360$ ), nor rainfall (Kendall $\tau=0.15, \mathrm{P}$ $=0.200)$. In spring, the standardized maximum number of Common Cranes was correlated with temperature (Kendall $\mathrm{t}$ $=-0.25, P=0.036$ ) and rainfall (Kendall $\mathrm{t}=0.29, \mathrm{P}=0.014)$, but not with water level (Kendall $t=0.21, P=0.078$ ). A multiple regression model supported water level as the significant predictor of Common Crane numbers in autumn (Appendix 1, Table A1.1).

The minimum number of Common Cranes wintering in Gallocanta also increased over the study period, from $1 \%$ of the previous autumn maximum in 1973 up to $40 \%$ in 2018 (Fig. 4). These percentages correlated negatively with water level (Kendall $\tau=-0.35, \mathrm{P}=0.004$ ) but not with temperature (Kendall $\tau=0.12$, $\mathrm{P}=0.330$ ) or rainfall (Kendall $\tau=0.05, \mathrm{P}=0.650$ ). A multiple regression model supported the water level as the explanatory variable of the number of cranes (Appendix 1, Table A1.1).

Fig. 4. Ratio of the minimum number of Common Cranes (Grus grus) in winter to the maximum number of Common Cranes during autumn migration throughout the study period. The continuous line shows a linear regression fit $(\mathrm{P}<0.001)$.

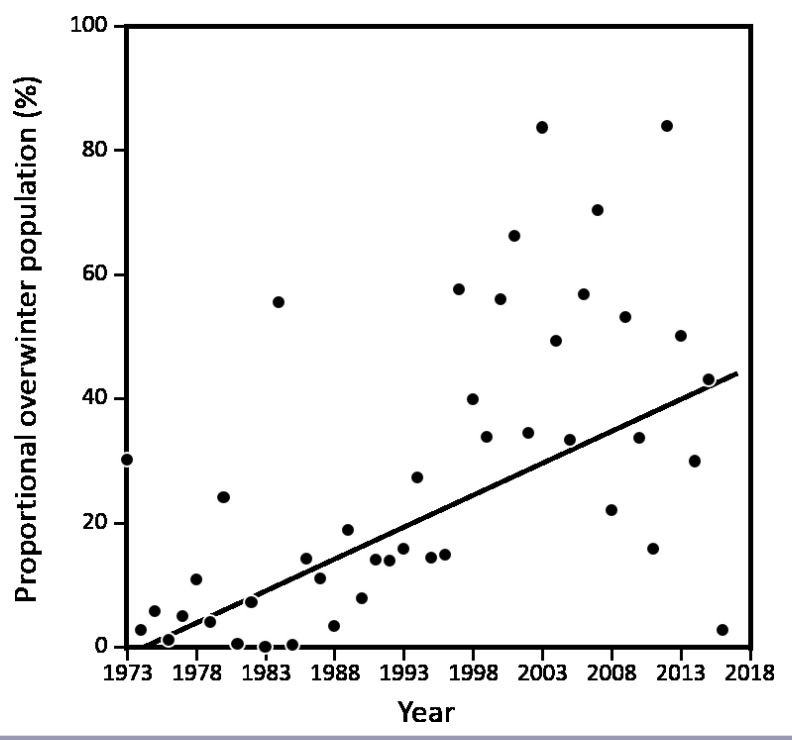

\section{Dates of migratory peaks and their relation with weather}

The spring migratory peak advanced 0.37 days/year (CI95\%: $0.23-0.53$ days/year, $\mathrm{P}<0.001)$, whereas in autumn the advance was statistically nonsignificant (Fig. 5). The date of the 50th percentile migration provided the same results: spring migration advanced 0.38 days/year (CI95\%: 0.22-0.50 days/year, $\mathrm{P}<0.001$ ) and autumn migration was statistically nonsignificant.

The dates of migratory peaks correlated negatively with temperature in both migrations (Fig. 6; autumn: Kendall $\tau=-0.24$, $\mathrm{P}=0.020$; spring: Kendall $\tau=-0.40, \mathrm{P}<0.001)$ and positively with water level only in spring (Kendall $\tau=0.36, \mathrm{P}<0.001$ ). Rainfall was not significantly correlated with migration timing, neither in spring (Kendall $\tau=0.16, \mathrm{P}=0.131$ ) nor in autumn (Kendall $\tau=0.04, \mathrm{P}=0.680$ ). In autumn, a multiple regression 
model supported the advancing effects caused by water level decreases and air temperature increments. In spring, the multiple regression highlighted water level as the only significant predictor: the lower the water level, the earlier the migratory peak (Appendix 2, Table A2.1).

Fig. 5. Date of maximum number of Common Cranes (Grus grus) in autumn (top) and spring (bottom) migrations. Common Cranes advanced the migration in spring 16.2 days $(\mathrm{P}<0.001)$ but not in autumn $(\mathrm{P}>$ $0.05)$. Lines show linear regression fits, respectively statistically significant (continuous line) and nonsignificant (dashed line).

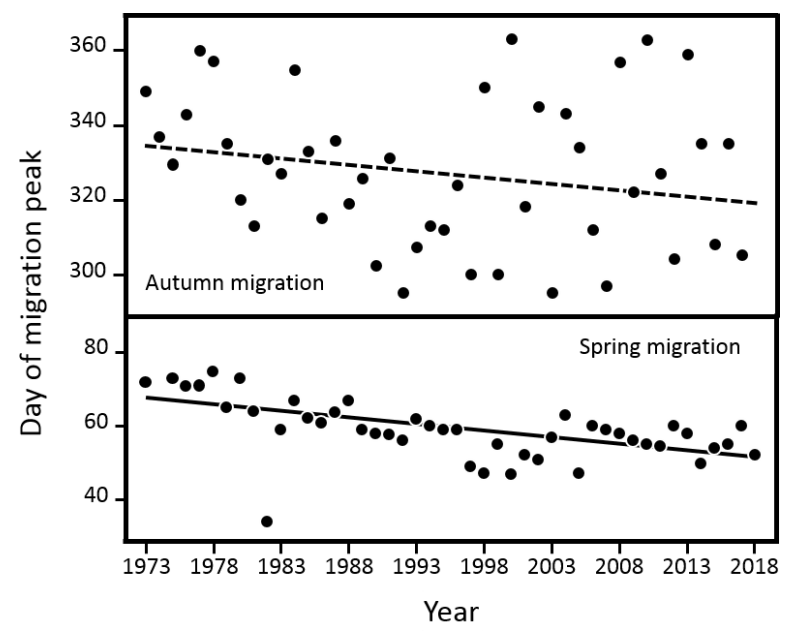

Fig. 6. Dates of migratory peaks in autumn (top) and spring (bottom) advanced with higher annual mean temperatures. Linear regression fits were statistically significant in autumn $(\mathrm{P}<0.05)$ and spring $(\mathrm{P}<0.01)$ : on average, Common Cranes (Grus grus) significantly advanced their migration time by 10.4 days in autumn and 11.6 days in spring per ${ }^{\circ} \mathrm{C}$ increase.

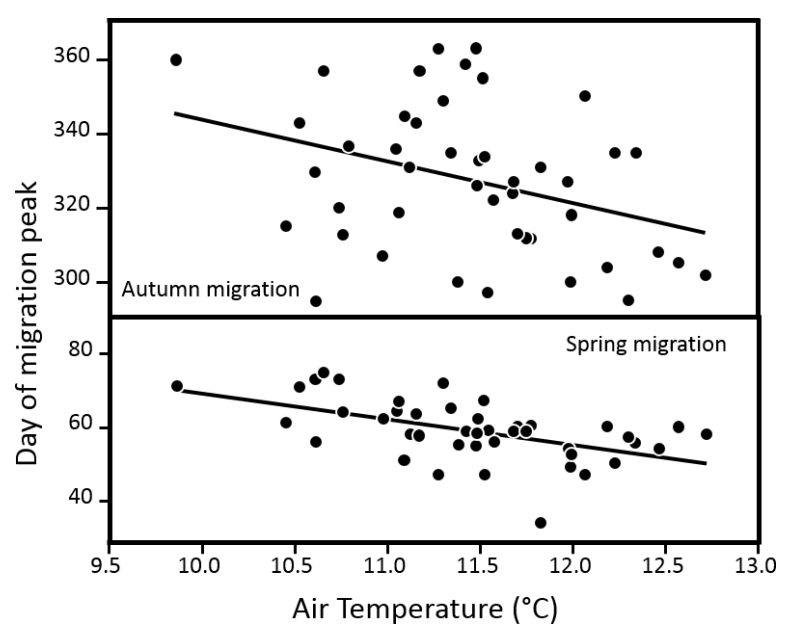

Pairwise nonparametric correlations of weather variables with the dates of the 50th percentile migration produced similar results: the 50th percentile correlated negatively with temperature in both migrations (autumn: Kendall $\tau=0.16, \mathrm{P}=0.133$; spring: Kendall $\tau=-0.23, \mathrm{P}<0.031)$ and positively with water level, but only in spring (Kendall $\tau=0.25, \mathrm{P}<0.019$ ). Rainfall was not significantly correlated with migration timing measured as the 50th percentile, neither in spring (Kendall $\tau=0.102, \mathrm{P}=0.336$ ) nor in autumn (Kendall $\tau=-0.005, \mathrm{P}=0.960$ ). A multiple regression model supported the advancing effect caused by decreases in water level and increments in air temperature on the dates of the 50th percentile migration in autumn. In spring only water level was a significant negative predictor of the 50th percentile migration (Appendix 2, Table A2.1).

Regarding the seasonal analysis, in spring the migration phenology was positively correlated with the residuals of the linear regression of mean water level $($ Kendall $\tau=0.33, P=0.001)$ and rainfall (Kendall $\tau=0.25, \mathrm{P}=0.018$ ). These correlations were not found during the autumn migratory period.

\section{DISCUSSION}

The results support our initial hypothesis that variations in the spring migration phenology of Common Cranes at a stopover site in southwestern Europe may be associated to climate change. Temperature, rainfall, and water level of the lagoon influenced the peak and 50th percentile migration dates and the number of individuals in the study area. Some caution must be taken, however, when interpreting the influence of climate change on the changes observed during the autumn migration and wintering periods.

The increase in air temperature in our study area was similar to those recorded in other areas of the Iberian Peninsula (GarcíaGarizábal and Causapé 2010), and also to trends reported for other Common Crane areas in Europe (e.g., $1.2{ }^{\circ} \mathrm{C}$ in France; Salvi 2012). Such increases have been explained as effects of global warming (IPCC 2013). In addition, certain long-term climatic cycles may also induce temperature and weather changes (IPCC 2013). For instance, both the North Atlantic Oscillation (NAO) and the Southern Oscillation could exert an influence at different, long-term temporal scales in Gallocanta, where drought phases of the lagoon every 14 years suggest a positive response to $\mathrm{El}$ Niño-Southern Oscillation signals, while no response to NAO have been observed (Rodo et al. 1997). One of the main limitations of climate change studies using birds as models is how rarely other potential causes of changing bird populations and behaviors are considered alongside climate change, to analyze multiple contributing drivers (Paxton et al. 2014, Møller and Dunn 2019).

Common Cranes in Gallocanta started their northward migration in spring 3.7 days per decade earlier. This advance in the date of the spring migration peak is similar to that reported for other birds (2.1 days per decade, Usui et al. 2017), including other crane species, and does not differ much from values reported for Common Cranes in other European sites (Palm et al. 2009, Lundgren 2012). Observations of Whooping Cranes between 1942 and 2016 showed an advance of almost three days per decade in their spring migration and a delay of the same magnitude in their autumn migration (Jorgensen and Brown 2017). The most obvious benefit adult pairs obtain from advancing spring migration is the possibility to start breeding earlier, thus having 
longer periods for raising their offspring before the next autumn migration. An additional benefit is to facilitate an earlier onset of the autumn migration, which has been reported in some studies (Filippi-Codaccioni et al. 2011, Végvári 2015). However, a temperature increase at the breeding grounds could favor a delay of the autumn migration (e.g. Volkov et al. 2016).

\section{Climate change and numbers of Common Cranes}

Cranes need a wetland to roost and drink water. Although previous studies have considered food as a limiting factor for Common Crane staging and wintering in Gallocanta (Alonso et al. 1987b, 1994, 2003, 2018), the effect of water as a limiting resource is poorly known. We used two variables, water level of the lagoon and rainfall. Although both are related (see Fig. 1), they have different meanings and implications for the number of Common Cranes. A certain water level is needed in order to provide suitable roosting sites for Common Cranes, and a minimum amount of rainfall is also required to fill the few streams and small ponds that birds use to drink water because the lagoon is saline. The water level of the lagoon fluctuated heavily since 1983, including some years when it dried up (Fig. 1). Common Cranes need $\sim 0.2 \mathrm{~m}$ water level for roosting, but that depth would force all birds to gather in too small an area, limiting the lagoon's carrying capacity as a roosting place. Years with a higher water level offered more sites to roost because the lagoon is large and very swallow. We found a positive correlation between number of Common Cranes in autumn and water level, supporting our inference about the impact of water level on the number of Common Cranes. However, we also found a negative correlation between wintering population and water level. This correlation may be explained by the influence of higher temperature, which accelerates evapotranspiration from the lagoon and favors the increasing number of wintering Common Cranes. Nevertheless, the relationship between water level and roosting behavior of Common Cranes in Gallocanta deserves further research.

Apart from water level, climate change also modifies food availability. Although the spring migration did not seem to depend on food availability (Alonso et al. 1990 a, b), in autumn Common Cranes tended to remain longer at Gallocanta, delaying the migration to wintering areas further south as long as enough food was available in Gallocanta (Alonso et al. 1994). Clearly, enough food availability is needed to remain in a stopover site (Alonso et al. 1994, 2018, Goss-Custard et al. 2002, 2003). This variable should have been included in the analyses, but this was not possible because food availability was not measured every year during the almost 45 years covered by the present study. However, it is worth highlighting that the high numbers of Common Cranes in January 1986 and 2014 (see Fig. 2) were preceded by cereal losses during harvest in summer due to bad weather, and that the grain left on the ground determined significant increases in food availability for Common Cranes during their autumn staging and well into the winter period in both years (Alonso et al. 1994, Sampietro et al. 2017).

\section{Effect of climate variables on migration phenology}

We found that the timing of peak Common Crane numbers in spring was influenced by temperature, occurring 11.6 days earlier per ${ }^{\circ} \mathrm{C}$ rise in mean annual air temperature (Fig. 6). Because temperature increased over the years, this resulted in an advance of 0.37 days/year in the spring migration peak. In autumn, the advance was 10.4 days per ${ }^{\circ} \mathrm{C}$ rise in air temperature. This advance was bigger than the average change reported for hundreds of migrating bird species across continents (1.2 to 1.7 days per ${ }^{\circ} \mathrm{C}$; Koláŕová et al. 2017, Usui et al. 2017), suggesting that the response scale of larger bodied birds could be different than that of smaller species.

As for the water level of the lagoon, the fluctuations over the period 1983-2018 were correlated with number of Common Cranes. A plausible explanation of such correlation is that low water levels prevent an accumulation of large numbers of Common Cranes because of a lack of enough suitable roosting sites in the shallow margins of the lagoon, as explained above. Moreover, both water level and rainfall during spring were correlated with the date when migration peak occurred. Our interpretation of this result is that both a too shallow water level in the lagoon and lack of sufficient spring rainfall enhance the effect of high temperatures, contributing to further advance the onset of northward migration from Gallocanta. Mean annual water level was negatively correlated with mean temperature and positively with annual rainfall, but temperature and rainfall did not correlate with the timing of migratory peaks, nor with maximum numbers of Common Cranes. This lack of a direct association highlights the main role of water level on the availability of roosting sites compared to temperature. Results obtained with linear mixed-effects models and alternative proxies for migration dates, i.e., dates of the $50 \%$ percentiles (Appendices 1 and 2) support this conclusion. Finally, spring migration in Gallocanta is speeded up by tail winds and delayed by cloudy skies and front winds (Alonso et al. 1990a, b), but local weather in spring was rather variable among years and cannot explain the advance of the spring migratory peak.

\section{Recent changes in Common Crane distribution and their effect on the timing and number of Common Cranes in Gallocanta}

Over the last decades the wintering range of Common Cranes in Western Europe has shifted northward (Alonso et al. 2003, Salvi 2012, 2013). In this context it is noteworthy that in response to warmer spring conditions, cranes migrating shorter distances have advanced their spring migratory phenology more than longdistance migrants (Usui et al. 2017). The advance in spring migration reported in the present study may be carefully considered before extrapolating it to future scenarios because of the species' current biogeographic situation, which is evidently changing and could increase the magnitude of the reported changes.

The overall critical lack of investigations on microevolutionary changes in bird phenology in response to climate change prevents drawing reliable conclusions on the processes underlying the observed patterns of advanced phenology in birds (Charmantier and Gienapp 2014, Cobben and van Noordwijk 2017). We can expect that increasing observations of individually marked Common Cranes in future years, e.g., iCora database (Crane Conservation Germany gGmbH, and NABU Crane Center 2018) will shed light on how Common Cranes track climate change along the western migratory route. 


\section{CONCLUSION}

In sum, Common Cranes have advanced their spring passage through Gallocanta over the last five decades. This shift in migration dates coincided with a change in climatic conditions. Because climate change is modifying ecological and climatic conditions in Gallocanta, potential alterations of food availability as well as roosting and drinking sites are likely. Although other migratory birds that did not show a phenological response to climate change are declining (Møller et al. 2008, Newson et al. 2016), a size increase of the Western Palearctic Common Crane population size is observed. Thus, further shifts in climate could continue favoring Common Cranes in northern Europe. However, in southern Europe the drying out of wetlands and desertification and deterioration of stopover and wintering areas could become a serious threat to the specie in the long term.

Responses to this article can be read online at: http://www.ace-eco.org/issues/responses.php/1565

\section{Acknowledgments:}

We thank the Government of Aragón for providing census data, and AEMET and CHE, who contributed with meteorological and hydrological data, respectively. Finally, we also acknowledge the contribution of María Pardos for requesting and compiling these data. The authors declare that they have no conflicts of interest. This work was performed within the framework of project AgroSOS (CGL2015-66016-R Spanish Ministry of Economy and Competitiveness - FEDER funds [EU]) and the Government of Aragón (Spain) through a predoctoral internship to J. M. Orellana (BOA 20/07/2017).

\section{LITERATURE CITED}

Aebischer, A., N. Perrin, M. Krieg, J. Studer, and D. R. Meyer. 1996. The role of territory choice, mate choice and arrival date on breeding success in the Savi's Warbler Locustella luscinioides. Journal of Avian Biology 27:143-152. https://doi.org/10.2307/3677143

Alonso, J. C., J. A. Alonso, and L. M. Bautista. 2018. A review of the crane-agriculture conflict at Gallocanta Lake, Spain. Pages 272-279 in J. E. Austin, K. L. Morrison, and J. T. Harris, editors. Cranes and agriculture: a global guide for sharing the landscape. International Crane Foundation, Baraboo, Wisconsin, USA.

Alonso, J. C., J. A. Alonso, and L. M. Bautista. 1994. Carrying capacity of staging areas and facultative migration extension in Common Cranes. Journal of Applied Ecology 31:212-222. https:// doi.org/10.2307/2404537

Alonso, J. A., J. C. Alonso, F. J. Cantos, and L. M. Bautista. 1990a. Spring crane Grus grus migration through Gallocanta, Spain. II. Timing and pattern of daily departures. Ardea 78:379-388.

Alonso, J. C., J. A. Alonso, F. J. Cantos, and L. M. Bautista. 1990 b. Spring crane Grus grus migration through Gallocanta, Spain. I. Daily variations in migration volume. Ardea 78:365-378.

Alonso, J. C., J. A. Alonso, J. H. Martínez, S. Avignon, and P. Petit. 2003. European cranes shift their wintering area northwards: new evidences from radio tagged birds. Pages 201-207 in A. Salvi, editor. Proceedings of 4th European Crane Workshop, Fénétrange, France, 2000. European Crane Working Group, Verdun, France.

Alonso, J. A., J. C. Alonso, and G. Nowald. 2008. Migration and wintering patterns of a central European population of Common Cranes Grus grus. Bird Study 55:1-7. https://doi.org/10.1080/00063650809461499

Alonso, J. C., J. A. Alonso, A. Onrubia, C. M. Cruz, R. Cangarato, and P. Rocha. 2016. Assessing four decades of wintering crane counts in Spain, Portugal and Morocco. Pages 28-37 in Friends of Gallocanta Association, editor. VIII European Crane Conference, held in Gallocanta, Spain, 2014. Asociación Amigos de Gallocanta, Gallocanta, Spain.

Alonso, J. C., J. A. Alonso, and J. P. Veiga. 1987a. Flocking in wintering Common Cranes Grus grus: influence of population size, food abundance and habitat patchiness. Ornis Scandinavica 18:53-60.

Alonso, J. C., J. P. Veiga, and J. A. Alonso. 1987b. Possible effects of recent agricultural development on the wintering and migratory patterns of Grus grus in Iberia. Pages 277-299 in G. W. Archibald and R. F. Pasquier, editors. Proceedings of the 1983 International Crane Workshop, Bharatpur, India, 1983. International Crane Foundation, Baraboo, Wisconsin, USA.

Bauer, S., S. Lisovski, and S. Hahn. 2016. Timing is crucial for consequences of migratory connectivity. Oikos 125:605-612. https://doi.org/10.1111/oik.02706

Bautista, L. M., J. C. Alonso, and J. A. Alonso. 1992. A 20-year study of wintering Common Crane fluctuations using time-series analysis. Journal of Wildlife Management 56:563-572. https://doi. org/10.2307/3808873

Castañeda, C., and J. Herrero. 2009. Remote sensing for detection of changes in Gallocanta Lake. Pages 105-128 in M. C. Seral and C. Castañeda, editors. Laguna de Gallocanta: Medio Natural, Conservacion y Teledeteccion. Real Sociedad Española de Historia Natural, Madrid, Spain.

Charmantier, A., and P. Gienapp. 2014. Climate change and timing of avian breeding and migration: evolutionary versus plastic changes. Evolutionary Applications 7:15-28. https://doi. org/10.1111/eva.12126

Chen, F. W., and C. W. Liu. 2012. Estimation of the spatial rainfall distribution using inverse distance weighting (IDW) in the middle of Taiwan. Paddy and Water Environment 10:209-222. https://doi. org/10.1007/s10333-012-0319-1

Cobben, M. M. P., and A. J. van Noordwijk. 2017. Consequences of the genetic threshold model for observing partial migration under climate change scenarios. Ecology and Evolution 7:8379-8387. https://doi.org/10.1002/ece3.3357

Cohen, E. B., Z. Németh, T. J. Zenzal, K. L. Paxton, R. Diehl, E. H. Paxton, and F. R. Moore. 2015. Spring resource phenology and timing of songbird migration across the Gulf of Mexico. Pages 63-82 in E. M. Wood and J. L. Kellermann, editors. Phenological synchrony and bird migration: changing climate and seasonal resources in North America. Studies in Avian Biology 47. CRC, Boca Raton, Florida, USA. 
Confederación Hidrográfica del Ebro. 1997. Balance de la unidad hidrogeológica de Gallocanta. Confederación Hidrográfica del Ebro, Zaragoza, Spain.

Confederación Hidrográfica del Ebro. 2002. Balance de la cuenca de la laguna de Gallocanta. Confederación Hidrográfica del Ebro, Zaragoza, Spain

Confederación Hidrográfica del Ebro. 2003. Establecimiento de las normas de explotación de la unidad hidrogeológica Gallocanta $y$ delimitación de los perímetros de protección de la laguna. Confederación Hidrográfica del Ebro, Zaragoza, Spain.

CORINE Land Cover. 2018. European Environment Agency. [online] URL: https://land.copernicus.eu/pan-european/corineland-cover

Crane Conservation Germany gGmbH, and NABU Crane Center. 2018. iCORA Internet Crane Observation Ring Archive. Crane Conservation Germany, Groß Mohrdorf, Germany. [online database] URL: https://www.icora.de

Dunn, P. O., and A. P. Møller. 2019. Effects of climate change on birds. Oxford University Press, Oxford, UK. https://doi. org/10.1093/oso/9780198824268.001.0001

Dunn, P. O., D. W. Winkler, L. A. Whittingham, S. J. Hannon, and R. J. Robertson. 2011. A test of the mismatch hypothesis: How is timing of reproduction related to food abundance in an aerial insectivore? Ecology 92:450-461. https://doi.org/10.1890/10-0478.1

Filippi-Codaccioni, O., J. P. Moussus, J. P. Urcun, and F. Jiguet. 2011. Advanced autumn migration of the Common Crane Grus grus over Western Pyrenean passes. Acta Ornithologica 46:37-45. https://doi.org/10.3161/000164511X589901

Forstmeier, W. 2002. Benefits of early arrival at breeding grounds vary between males. Journal of Animal Ecology 71:1-9. https:// doi.org/10.1046/j.0021-8790.2001.00569.x

García, M. A., J. San Roman, O. Blasco, and P. Coloma. 2009. Hydrogeology of the Gallocanta Lake and environmental implications. Pages 79-103 in M. C. Seral and C. Castañeda, editors. Laguna de Gallocanta: Medio Natural, Conservacion y Teledeteccion. Real Sociedad Española de Historia Natural, Madrid, Spain.

García-Garizábal, I., and J. Causapé. 2010. Influence of irrigation water management on the quantity and quality of irrigation return flows. Journal of Hydrology 385:36-43. https://doi. org/10.1016/j.jhydrol.2010.02.002

Gobierno de Aragón. 2018. Seguimiento de la grulla común en la Laguna de Gallocanta y su entorno. Departamento de Desarrollo Rural y Sostenibilidad, Zaragoza, Spain.

Goss-Custard, J. D., R. A. Stillman, A. D. West, R. W. Caldow, and S. McGrorty. 2002. Carrying capacity in overwintering migratory birds. Biological Conservation 105:27-41. https://doi. org/10.1016/S0006-3207(01)00175-6

Goss-Custard, J. D., R. A. Stillman, R. W. G. Caldow, A. D. West, and M. Guillemain. 2003. Carrying capacity in overwintering birds: when are spatial models needed? Journal of Applied Ecology 40:176-187. https://doi.org/10.1046/j.1365-2664.2003.00785.x
Harris, J., and G. W. Archibald. 2013. Status of and threats to the cranes of the world. Pages 7-15 in G. Nowald, A. Weber, J. Fanke, E. Weinhardt, and N. Donner, editors. Proceedings of the VII European Crane Conference- Breeding, resting, migration and biology, Stralsund, Germany, 2010. Crane Conservation Germany, Groß Mohrdorf, Germany.

Helsel, D. R., and R. M. Hirsch. 2002. Statistical methods in water resources. U.S. Geological Survey, U.S. Department of the Interior, Washington, D.C., USA.

Hernández, F. 1986. Situacion y evolucion de la poblacion invernante de la Grulla Común en Gallocanta. Jornadas sobre problematica y conservacion de la Grulla Común Grus grus en áreas de invernada en España. Diputación General de Aragón, Zaragoza, Spain.

Iglesias, M., and A. Bone. 2006. Plan de Ordenación de los Recursos Naturales (PORN) de la Zona de Especial Protección para las Aves (ZEPA) de la Laguna de Gallocanta. Boletín Oficial de Aragón 22:2210-2275.

Intergovernmental Panel on Climate Change (IPCC). 2013. Climate change 2013: the physical science basis. Contribution of Working Group I to the Fifth Assessment Report of the Intergovernmental Panel on Climate Change. Cambridge University Press, Cambridge, UK. https://doi.org/10.1017/ cbo9781107415324.023

Jorgensen, J. G., and M. B. Brown. 2017. Temporal migration shifts in the Aransas-Wood Buffalo Population of Whooping Cranes (Grus americana) across North America. Waterbirds 40:195-206. https://doi.org/10.1675/063.040.0302

Knudsen, E., A. Lindén, C. Both, N. Jonzén, F. Pulido, N. Saino, W. J. Sutherland, L. A. Bach, T. Coppack, T. Ergon, P. Gienapp, J. A. Gill, O. Gordo, A. Hedenström, E. Lehikoinen, P. P. Marra, A. P. Møller, A. L. Nilsson, G. Péron, E. Ranta, D. Rubolini, T. H. Sparks, F. Spina, C. E. Studds, S. A. Sæther, P. Tryjanowski, and N. C. Stenseth. 2011. Challenging claims in the study of migratory birds and climate change. Biological Reviews 86:928-946. https://doi.org/10.1111/j.1469-185X.2011.00179.x

Kokko, H. 1999. Competition for early arrival in migratory birds. Journal of Animal Ecology 68:940-950. https://doi.org/10.1046/ j.1365-2656.1999.00343.x

Kolářová, E., M. Matiu, A. Menzel, J. Nekovář, P. Lumpe, and P. Adamik. 2017. Changes in spring arrival dates and temperature sensitivity of migratory birds over two centuries. International Journal of Biometeorology 61:1279-1289. https://doi.org/10.1007/ s00484-017-1305-5

Kraft, M. 1999. Systematic counts of Common Cranes Grus grus during autumn migration from 1987 to 1998 in Marburg/Lahn area, Germany. Vogelwelt 120:337-343.

Kuhn, N. J., R. Baumhauer, and B. Schütt. 2011. Managing the impact of climate change on the hydrology of the Gallocanta Basin, NE-Spain. Journal of Environmental Management 92:275-283. https://doi.org/10.1016/j.jenvman.2009.08.023

Kurtzman, D., S. Navon, and E. Morin. 2009. Improving interpolation of daily precipitation for hydrologic modelling: 
Avian Conservation and Ecology 15(1): 16

spatial patterns of preferred interpolators. Hydrological Processes 23:3281-3291. https://doi.org/10.1002/hyp.7442

Ligue pour la Protection des Oiseaux (LPO)/Birdlife. 2018. Information about migration sites and Common Cranes. LPO/ BirdLife, Outines, France.

Lundgren, S. 2012. Cranes and climate change in Sweden. Pages 49-52 in J. Harris, editor. Cranes, agriculture and climate change. International Crane Foundation, Baraboo, Wisconsin, USA.

Marra, P. P., C. M. Francis, R. S. Mulvihill, and F. R. Moore. 2005. The influence of climate on the timing and rate of spring bird migration. Oecologia 142:307-315. https://doi.org/10.1007/ s00442-004-1725-x

Mewes, W., and M. Rauch. 2012. Influence of climate change on the beginning of breeding of Eurasian cranes in Germany. Pages 53-54 in J. Harris, editor. Cranes, agriculture and climate change. International Crane Foundation, Baraboo, Wisconsin, USA.

Miller-Rushing, A. J., R. B. Primack, and R. Stymeist. 2008. Interpreting variation in bird migration times as observed by volunteers. Auk 125:565-573. https://doi.org/10.1525/auk.2008.07005

Mingozzi, T., P. Storino, G. Venuto, G. Alessandria, E. Arcamone, S. Urso, L. Rugieri, L. Massetti, and A. Massolo. 2013. Autumn migration of Common Cranes Grus grus through the Italian Peninsula: new vs. historical flyways and their meteorological correlates. Acta Ornithologica 48:165-177. https://doi. org/10.3161/000164513X678810

Møller, A. P., and P. O. Dunn. 2019. Conclusions. Pages 265-267 in P. O. Dunn and A. P. Møller, editors. Effects of climate change on birds. Oxford University Press, Oxford, UK. https://doi. org/10.1093/oso/9780198824268.003.0019

Møller, A. P., D. Rubolini, and E. Lehikoinen. 2008. Populations of migratory bird species that did not show a phenological response to climate change are declining. Proceeding of the National Academy of Sciences of the United States of America 105:16195-16200. https://doi.org/10.1073/pnas.0803825105

Newson, S. E., N. J. Moran, A. J. Musgrove, J. W. Pearce-Higgins, S. Gillings, P. W. Atkinson, R. Miller, M. J. Grantham, and S. R. Bailie. 2016. Long-term changes in the migration phenology of UK breeding birds detected by large-scale citizen science recording schemes. Ibis 158:481-495. https://doi.org/10.1111/ ibi. 12367

Nowald, G., N. Donner, and M. Modrow. 2012. Influence of climate change on the wintering site selection of Eurasian cranes. Pages 55-59 in J. Harris, editor. Cranes, agriculture and climate change. International Crane Foundation, Baraboo, Wisconsin, USA.

Ojaste, I., A. Leito, P. Suorsa, A. Hedenström, K. Sepp, M. Leivits, U. Sellis, and Ü. Väli. 2020. From northern Europe to Ethiopia: long-distance migration of Common Cranes (Grus grus). Ornis Fennica 97:00-00.

Palm, V., A. Leito, J. Truu, and O. Tomingas. 2009. The spring timing of arrival of migratory birds: dependence on climate variables and migration route. Ornis Fennica 86:97-108.

Palm, V., M. Sepp, J. Truu, R. D. Ward, and A. Leito. 2017. The effect of atmospheric circulation on spring arrival of short- and long-distance migratory bird species in Estonia. Boreal Environmental Research 22:97-114.

Paxton, K. L., E. B. Cohen, E. H. Paxton, Z. Németh, and F. R. Moore. 2014. El Niño-Southern Oscillation is linked to decreased energetic condition in long-distance migrants. PLoS ONE 9(5): e95383. https://doi.org/10.1371/journal.pone.0095383

Prange, H. 2005. The status of the Common Crane (Grus grus) in Europe: breeding, resting, migration, wintering and protection. Pages 69-77 in F. Chavez-Ramirez, editor. Proceedings of th 9th North American Crane Workshop. North American Crane Workshop, Baraboo, Wisconsin, USA.

Prange, H. 2012. Reasons for changes in crane migration patterns along the west-European flyway. Pages 35-48 in J. Harris, editor. Cranes, agriculture and climate change. International Crane Foundation, Baraboo, Wisconsin, USA.

Prange, H. 2016. Die Welt der Kraniche. MediaNatur Verlag. University of Halle, Wittenberg Halle, Germany.

Prieta, J., and J. C. del Moral. 2009. La grulla común invernante en España: Población en 2007 y método de censo. SEO/BirdLife, Madrid, Spain.

R Development Core Team. 2016. R: A language and environment for statistical computing. R Foundation for Statistical Computing. [online] URL: http://www.R-project.org

Ramenofsky, M., and J. C. Wingfield. 2007. Regulation of migration. Bioscience 57:135-143. https://doi.org/10.1641/ B570208

Rodó, X., E. Baert, and F. A. Comín. 1997. Variations in seasonal rainfall in southern Europe during the present century: relationships with the North Atlantic Oscillation and the El Niño Southern Oscillation. Climate Dynamics 13:275-284. https://doi. org/10.1007/s003820050165

Román, J. A. 2018. Population size of the Common crane (Grus grus) in Spain in the wintering season 2017/2018. Ardeola 65:328.

Salmi, T., A. Määttä, P. Anttila, T. Ruoho-Airola, and T. Amnell. 2002. Detecting trends of annual values of atmospheric pollutants by the Mann-Kendall test and Sen's Slope estimates The Excel Template application MAKESENSE. Finnish Meteorological Institute. Publications on Air Quality 31:1-35.

Salvi, A. 2012. Eurasian Crane (Grus grus) and climate change in France. Pages 71-76 in J. Harris, editor. Cranes, agriculture and climate change. International Crane Foundation, Baraboo, Wisconsin, USA.

Salvi, A. 2013. Eurasian Crane Grus grus study in France over the last 30 years. Pages 30-37 in G. Nowald, A. Weber, J. Fanke, E. Weinhardt, and N. Donner, editors. Proceedings of the VII European Crane Conference - Breeding, resting, migration and biology. Crane Conservation Germany, Groß Mohrdorf, Germany.

Salvi, A. 2016. The Camargue, confluence of the European migratory flyways of the Eurasian Crane Grus grus. Aves 53:49-68.

Sampietro, F. J., E. Pelayo, J. L. Riva, and J. Sanz. 2017. Invernada excepcional de grulla común (Grus grus) en el área de la laguna 
de Gallocanta durante el invierno 2013-2014. Anuario Ornitológico de Aragón 8:59-67.

Schmaljohann, H., and C. Both. 2017. The limits of modifying migration speed to adjust to climate change. Nature Climate Change 7:573-576. https://doi.org/10.1038/nclimate3336

Smith, R. J., and, F. R. Moore. 2005. Arrival timing and seasonal reproductive performance in a long-distance migratory landbird. Behavioral Ecology and Sociobiology 57:231-239. https://doi. org/10.1007/s00265-004-0855-9

Teitelbaum, C. S., S. J. Converse, W. F. Fagan, K. Böhning-Gaese, R. B. O'Hara, A. E. Lacy, and T. Mueller. 2016. Experience drives innovation of new migration patterns of whooping cranes in response to global change. Nature Communications 7:12793. https://doi.org/10.1038/ncomms12793

Usui, T., S. H. M. Butchart, and A. B. Phillimore. 2017. Temporal shifts and temperature sensitivity of avian spring migratory phenology: a phylogenetic meta-analysis. Journal of Animal Ecology 86:250-261. https://doi.org/10.1111/1365-2656.12612

Végvári, Z. 2015. Autumn crane migration and climate change in the Carpathian Basin. Ornis Hungarica 23:31-38. https://doi. org/10.1515/orhu-2015-0012

Végvári, Z., V. Bókony, Z. Barta, and G. Kovács. 2010. Life history predicts advancement of avian spring migration in response to climate change. Global Change Biology 16:1-11. https://doi. org/10.1111/j.1365-2486.2009.01876.x

Végvári, Z., and G. Kovacs. 2012. The effects of climate change on the migratory patterns of the Eurasian Crane in the BalticHungarian flyway. Pages 83-88 in J. Harris, editor. Cranes, agriculture and climate change. International Crane Foundation, Baraboo, Wisconsin, USA.

Visser, M. E., L. J. M. Holleman, and P. Gienapp. 2006. Shifts in caterpillar biomass phenology due to climate change and its impact on the breeding biology of an insectivorous bird. Oecologia 147:164-172. https://doi.org/10.1007/s00442-005-0299-6

Volkov, S. V., O. S. Grinchenko, and T. V. Sviridova. 2016. The effects of weather and climate changes on the timing of autumn migration of the Common Crane (Grus grus) in the north of Moscow region. Biological Bulletin 43:1203-1211. https://doi. org/10.1134/S1062359016110170

Editor-in-Chief: Alexander L.Bond Subject Editor: Auriel M.V.Fournier

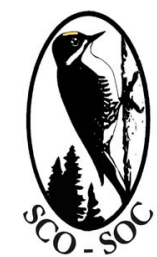

Sponsored by the Society of Canadian Ornithologists and Birds Canada

Parrainée par la Société des ornithologistes du Canada et Oiseaux Canada

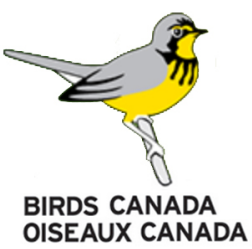




\section{Appendix 1. Multiple linear model: number of cranes vs abiotic conditions}

Table A1.1. Multiple linear models of abiotic variables (temperature, water level and rainfall) as predictors of the maximum number of Common Cranes in autumn and spring, but minimum number of wintering cranes in January. Abiotic variables were averaged for the whole year (365 days). Regression coefficients and standard errors $(\underline{+\mathrm{SE}})$ are shown with $t$-values and P-values.

\begin{tabular}{|c|c|c|c|c|c|c|c|c|c|}
\hline & \multicolumn{3}{|l|}{ Autumn } & \multicolumn{3}{|l|}{ Winter } & \multicolumn{3}{|l|}{ Spring } \\
\hline & Estimate $\pm \mathrm{SE}$ & $t$ & $\mathrm{P}$ & Estimate $\pm \mathrm{SE}$ & $t$ & $\mathrm{P}$ & Estimate $\pm \mathrm{SE}$ & $t$ & $\mathrm{P}$ \\
\hline Temperature & $6.03 \pm 6.57$ & 0.92 & 0.336 & $-4.38 \pm 6.91$ & 0.63 & 0.532 & $-15.90 \pm 14.88$ & -1.07 & 0.294 \\
\hline Water level & $55.90 \pm 16.41$ & 3.41 & 0.002 & $-24.67 \pm 8.04$ & 3.07 & 0.004 & $48.50 \pm 31.28$ & 1.55 & 0.131 \\
\hline Rainfall & $0.06 \pm 0.04$ & 1.62 & 0.116 & $0.02 \pm 0.04$ & 0.53 & 0.600 & $0.12 \pm 0.09$ & 1.34 & 0.191 \\
\hline intercept & $-108 \pm 80$ & -1.35 & 0.189 & $80 \pm 85$ & 0.94 & 0.351 & $211.94 \pm 183.45$ & 1.16 & 0.257 \\
\hline Model & \multicolumn{3}{|c|}{$\mathrm{F}_{3,39}=6.92, \mathrm{P}<0.001$} & \multicolumn{3}{|c|}{$\mathrm{F}_{3,39}=4.01, \mathrm{P}=0.014$} & \multicolumn{3}{|c|}{$\mathrm{F}_{3,31}=3.184, \mathrm{P}=0.037$} \\
\hline
\end{tabular}




\section{Appendix 2. Multiple linear model: dates of the maximum number and the 50th percentile of Common Cranes counts vs abiotic}

conditions

Table A2.1. Multiple linear models of abiotic variables (temperature, water level and rainfall) as predictors of the Julian day of (a) the maximum number of Common Cranes (migratory peak) and (b) the 50th percentile of Common Cranes counts in autumn and spring migrations. Regression coefficients and standard errors $( \pm \mathrm{SE})$ are shown with $t$-values and P-values.

\begin{tabular}{|c|c|c|c|c|c|c|c|}
\hline \multirow[b]{2}{*}{ Date type } & \multirow[b]{2}{*}{ Abiotic variables } & \multicolumn{3}{|l|}{ Autumn } & \multicolumn{3}{|l|}{ Spring } \\
\hline & & Estimate $\pm \mathrm{SE}$ & $t$ & $\mathrm{P}$ & Estimate $\pm \mathrm{SE}$ & $t$ & $\mathrm{P}$ \\
\hline
\end{tabular}

(a) Migratory peak

\begin{tabular}{|c|c|c|c|c|c|c|}
\hline Temperature & $-12.0 \pm 6.30$ & -1.92 & 0.063 & $-2.9 \pm 2.0$ & -1.46 & 0.052 \\
\hline Water level & $-1.8 \pm 7.30$ & -0.25 & 0.805 & $7.0 \pm 2.30$ & 3.05 & 0.004 \\
\hline Rainfall & $-0.003 \pm 0.038$ & -0.09 & 0.928 & $0.005 \pm 0.01$ & 0.40 & 0.693 \\
\hline intercept & $467 \pm 77$ & 77 & $<0.001$ & $86 \pm 24$ & 3.57 & $<0.001$ \\
\hline Model & $\mathrm{F}_{3,39}=1.74, \mathrm{P}=0$ & & & $\mathrm{~F}_{3,39}=10.33$ & 0.001 & \\
\hline
\end{tabular}

(b) $50^{\text {th }}$ percentile

\begin{tabular}{llllllll} 
Temperature & $3.93 \pm 1.89$ & 2.07 & 0.04 & $-1.37 \pm 2.61$ & -0.526 & 0.602 \\
Water level & $2.72 \pm 2.20$ & 1.24 & 0.22 & $5.391 \pm 3.04$ & 1.774 & 0.084 \\
Rainfall & $-0.004 \pm 0.01$ & -0.4 & 0.698 & $-0.007 \pm 0.02$ & -0.438 & 0.664 \\
intercept & $276.7 \pm 23.2$ & 11.9 & $<0.001$ & $67.9 \pm 32.07$ & 2.12 & 0.041 \\
\hline Model & $\mathrm{F}_{3,39}=1.58, \mathrm{P}=0.215$ & & $\mathrm{~F}_{3,39}=2.48, \mathrm{P}=0.08$ \\
\hline
\end{tabular}

